\title{
Quantifying sublethal Florida manatee-watercraft interactions by examining scars on manatee carcasses
}

\author{
Brandon L. Bassett ${ }^{1, *}$, Jeffrey A. Hostetler ${ }^{1}$, Erin Leone ${ }^{2}$, Colin P. Shea ${ }^{3}$, \\ Brittany D. Barbeau ${ }^{1}$, Gina L. Lonati ${ }^{1,4}$, Anna L. Panike ${ }^{1}$, Allison Honaker ${ }^{1}$, \\ Leslie I. Ward-Geiger ${ }^{1}$
}

\begin{abstract}
${ }^{1}$ Fish and Wildlife Research Institute, Florida Fish and Wildlife Conservation Commission, St. Petersburg, FL 33701, USA
${ }^{2}$ Center for Biostatistics and Modeling, Information Science and Management, Fish and Wildlife Research Institute, Florida Fish and Wildlife Conservation Commission, Gainesville, FL 32653, USA

${ }^{3}$ Center for Biostatistics and Modeling, Information Science and Management, Fish and Wildlife Research Institute, Florida Fish and Wildlife Conservation Commission, St. Petersburg, FL 33701, USA
\end{abstract}

${ }^{4}$ Department of Biological Sciences, University of New Brunswick Saint John, Saint John, New Brunswick E2L 4L5, Canada

\begin{abstract}
A leading human-related threat to the Florida manatee Trichechus manatus latirostris is collisions with watercraft, which account for $20-25 \%$ of reported mortalities. Quantitative threat assessments do not include information on all known manatee-watercraft interactions. These interactions often result in sublethal wounding, usually leaving multiple fresh external wounds in a variety of patterns. These wounds then resolve into well-healed scars. We characterized and quantified watercraft-related scar patterns (1 pattern $=1$ strike event) on 2935 nonperinatal carcasses (>150 cm total length) that were recovered from 2007 through 2016 to compare the number of patterns by life stage, sex, and population region and across years. We used generalized linear mixed models to examine the effects of several factors on the probability of carcasses having scars and on the number of scar patterns per carcass. The models indicated that approximately $96 \%$ of adults, approximately $70 \%$ of subadults, and approximately $34 \%$ of calves had watercraft-related scars. The raw data showed that 1 in 4 adults had been hit 10 or more times; 5 adult carcasses bore evidence of 40 or more strikes. On average, adult females had more scar patterns than did adult males. Manatees on Florida's west coast had more scar patterns than did those on the east coast, while carcasses from the less populated Everglades had significantly fewer scar patterns than did those from the rest of the state. These results improve our understanding of the extent of sublethal injury of the Florida manatee caused by boat strikes.
\end{abstract}

KEY WORDS: Florida manatee $\cdot$ Trichechus manatus latirostris $\cdot$ Watercraft $\cdot$ Scars $\cdot$ Sublethal strikes $\cdot$ Marine mammal $\cdot$ Human interaction

\section{INTRODUCTION}

The Florida manatee Trichechus manatus latirostris is a herbivorous marine mammal that inhabits the coastal waterways, inland lakes, and rivers of the southeastern USA. This subspecies of the West Indian manatee is protected under US state and federal laws including the Florida Manatee Sanctuary Act (1978),

\footnotetext{
*Corresponding author: brandon.bassett@myfwc.com
}

the Endangered Species Act (1973), and the Marine Mammal Protection Act (1972). The Florida Manatee Recovery Plan (USFWS 2001) identifies 4 generalized population regions in Florida that reflect manatees' fidelity to overwintering sites: Northwest (NW), Southwest (SW), Atlantic (ATL), and Upper St. Johns (USJ) (Fig. 1). In the spring, manatees may disperse and travel between regions and to a lesser extent be-

(C) The authors 2020. Open Access under Creative Commons by Attribution Licence. Use, distribution and reproduction are unrestricted. Authors and original publication must be credited. 


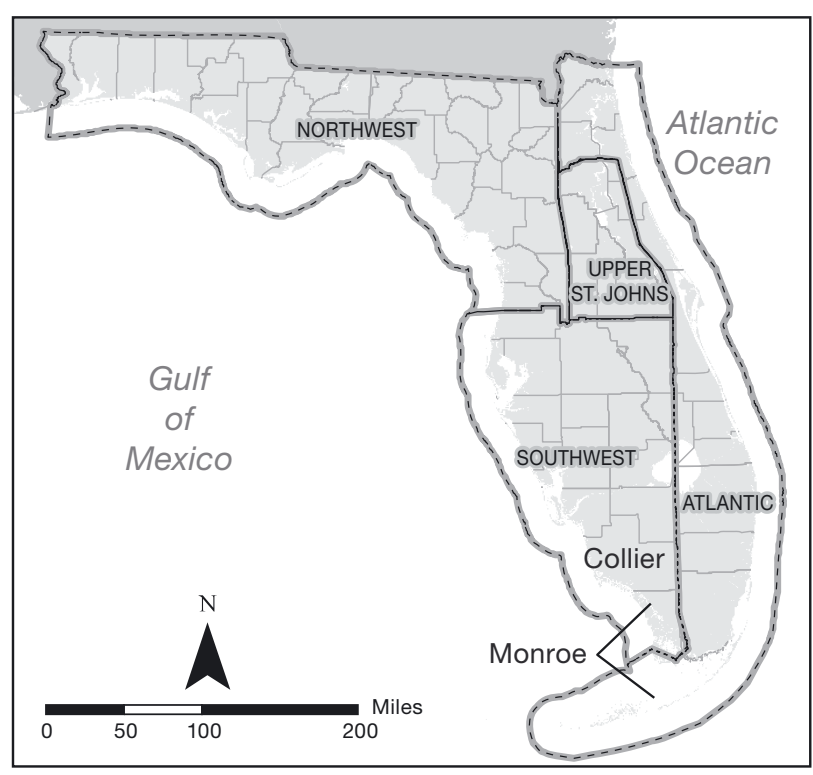

Fig. 1. US Fish and Wildlife Service Florida manatee population regions: Northwest (NW); Southwest (SW); Atlantic (ATL); Upper St. Johns (USJ), with Collier and Monroe counties identified. Monroe County is split between the SW and ATL regions

tween coasts or to other states (Weigle et al. 2001, Deutsch et al. 2003). However, studies suggest that during the warm season most manatees remain within the same region in which they over-wintered (Bengtson 1981, Rathbun et al. 1990, Reid et al. 1991, Weigle et al. 2001, Deutsch et al. 2003, Stith et al. 2006). Manatees share the waterways with hundreds of thousands of watercraft: registered watercraft (https://www.flhsmv.gov/motor-vehicles-tags-titles/ vessels/vessel-owner-statistics), unregistered watercraft, and watercraft visiting Florida from other states or countries (Wright et al. 1995). Watercraft harm manatees and a variety of marine wildlife including cetaceans (Wells \& Scott 1997, Stone \& Yoshinaga 2000, Fonnesbeck et al. 2008, Wells et al. 2008, Conn \& Silber 2013, Christiansen et al. 2016) and sea turtles (Hazel \& Gyuris 2006, Hazel et al. 2007, Singel et al. 2008, Sobin \& Eckert 2008). It has long been known that collisions with watercraft are a significant threat to the Florida manatee (Wright et al. 1995, USFWS 2001, Lightsey et al. 2006, FWC 2007, Runge et al. 2017), and regulations regarding the operation and speed of motorized watercraft in specified areas are important aspects of protection efforts (Calleson \& Frohlich 2007, Calleson 2014, Rycyk et al. 2018, Udell et al. 2019). Trauma to manatees from watercraft results from both sharp and blunt forces, and either type of impact can result in death (Lightsey et al. 2006). Previous research categorized lethal wounds caused by both sharp- and blunt-force traumatic collisions with watercraft and demonstrated that wound patterns generated by collisions with watercraft are diagnostic (Lightsey et al. 2006, Rommel at al. 2007). From 1974 through 2016, 10964 manatee carcasses were reported in Florida, of which 2325 of the deaths were watercraft-related $(21 \%)$. Considering only the 6185 necropsies in which the cause of death could be determined, the 2325 watercraft-related mortalities accounted for $38 \%$ of known causes of death. Taking undetermined necropsy cases into account, an estimate of the fractions of mortality resulting from various causes also indicates high proportions of deaths due to watercraft, underscoring the need for long-term vigilance in conservation actions (Runge et al. 2017). Statewide rescue operations coordinated by the Florida Fish and Wildlife Conservation Commission (FWC) provide additional information on threats to the population (https://myfwc.com/research/ manatee/rescue-mortality-response/statistics/rescue/ yearly/). From 2007 through 2016, a total of 174 manatees were rescued following collisions with watercraft, and of those, $104(60 \%)$ succumbed to their injuries during rehabilitation.

In manatees, a thick, fibrous dermis made of tightly woven collagen fibers underlies a thin epidermis which, combined, can be 5 times as thick as the combined layers in land mammals of similar mass. The radial and helical orientations of the dermal fibers provide resistance to shearing forces in nearly all directions. This structure and thickness also affords resistance to tears and erosion due to trauma and, in dead animals, due to decomposition or handling (Kipps 2000, Kipps et al. 2002). But in manatees that survive a trauma, damage to the dermis can leave permanent scars. The surface of normal manatee skin has a dimpled or papillary texture, while scarred skin has a smooth or striated appearance. The epidermis associated with permanent scars may appear white due to a lack of pigmentation in the new tissue, but over time it may return to its normal gray coloration. Nonpermanent scars have been observed through photo-identification programs from damage limited to the epidermis in some naturally acquired wounds or in some superficial watercraft wounds (FWC unpubl. data).

Additional information on the frequency and extent of collisions between manatees and watercraft can be gleaned from manatees' scar patterns ( $\mathrm{O}$ 'Shea et al. 2001). Persistent dermal scars are the basis of the Manatee Individual Photo-identification System (MIPS), a multiagency database (FWC, Mote Marine Lab, US Geological Survey [USGS]) managed by the USGS of long-term photo-identification monitoring 
programs in Florida. MIPS allows users to employ scars, tail and body mutilations, and related sighting information to identify individuals and estimate their survival and reproductive rates through markrecapture methods (Beck \& Reid 1995, Langtimm et al. 2004, 2016, Kendall et al. 2012); these estimates are critical components of population models (Runge et al. 2017). MIPS does not track when new scars are acquired or identify patterns of scars (i.e. multiple propeller scars) associated with individual strike events, which would be required to identify a minimum number of boat encounters over time. Although calves, subadults, and adults have been observed with watercraft-related scars, the percentages of catalogued individuals with scars and the number of scar patterns per individual have not been published.

Standardized necropsy procedures include recording all scars on every recovered carcass using photographs, scar sketches, and written descriptions. Sublethal collisions with watercraft often cause wounds that can heal into a single scar per encounter or multiple scars per encounter in distinctive patterns, such as those caused by multiple propeller wounds. All scars related to a single watercraft strike are herein referred to as a scar pattern. While scars observed on recovered carcasses have been reported briefly (Beck et al. 1982, Wright et al. 1995), a large-scale examination of the data on accumulation patterns and rates has not been performed. In this study, we used $10 \mathrm{yr}$ of scar documentation collected as part of the FWC manatee necropsy program to characterize and quantify watercraft-related scarring across life stages, sex, population regions, and years. Our goal was to advance our understanding of sublethal watercraft-related impacts on the Florida manatee.

\section{MATERIALS AND METHODS}

We examined the necropsy records of all 3786 nonperinatal carcasses (i.e. $>150 \mathrm{~cm}$ in total straight length) recovered in Florida from 2007 through 2016. Life stages are defined as calves $(>150$ and $<236 \mathrm{~cm})$, subadults $(236-265 \mathrm{~cm})$, and adults $(>265 \mathrm{~cm}$ ) (Barlas et al. 2011, Runge et al. 2017).

Fresh lethal wound pattern appearance has been previously described to varying degrees (Lightsey et al. 2006, Rommel at al. 2007), but detailed descriptions of the full range of wound appearances are limited in the literature. We standardized the scar pattern identification process based on the appearance of the 3 most common types of lethal watercraftrelated wounds observed in carcasses (Texts S1 and
S2, Figs. S1 \& S2 in the Supplement at www.int-res. com/articles/suppl/n043p395_supp.pdf), because fresh sublethal wounds appear to heal into recognizable well-healed scars. Collisions with watercraft most often result in (1) a series of relatively evenly spaced, parallel wounds from propellers or parallel projections from the hull, (2) a single linear or roughly triangular wound from a skeg, rudder, hull, or single propeller strike, or (3) a combination of these wound types. These types of wounds were distinguishable from wounds caused by something other than a collision with a watercraft (Text S3, Fig. S3). Carcasses were removed from the study if the dermis had been severely eroded due to decomposition (i.e. the papillary or dimpled structure was no longer visible), if large portions of the dermis were missing or had been severely damaged due to scavenging or trauma, or if the dorsum could not be examined due to extenuating circumstances such as challenging field conditions. This left 2935 carcasses for analysis (Table 1).

\subsection{Carcass processing and identification of scar patterns}

Scars were recorded during standardized necropsies of carcasses (Bonde et al. 1983). First, a carcass was photographed from dorsal, lateral, and ventral aspects; a dorsal photograph of the fluke was also taken. Next, the carcass was closely examined for scarred skin, which can be differentiated from unscarred skin by differences in texture and sometimes color. Well-healed scars can often appear hypopigmented and smoother than surrounding skin (Lightsey et al. 2006), but the epidermis can sometimes return to its normal gray coloration. The skin texture

Table 1. Number of examined Florida manatee carcasses, 2007-2016, by sex, life stage, and population region

\begin{tabular}{|lc|}
\hline & No. of carcasses \\
\hline Sex & \\
Male & 1486 \\
Female & 1444 \\
Undetermined & 5 \\
Life stage & \\
Calf & 997 \\
Subadult & 553 \\
Adult & 1385 \\
Population region & \\
Northwest & 134 \\
Southwest & 1342 \\
Atlantic & 1375 \\
Upper St. Johns & 84 \\
\hline
\end{tabular}


is sometimes easy to evaluate with the epidermis intact, but the epidermis can occasionally thicken due to environmental stresses (e.g. disease, temperature) or become obscured by algae or other epibiota. Differentiating between unscarred skin and scarred skin becomes more difficult in these cases, and a scar is sometimes easier to identify by examining the dermis rather than by examining the epidermis. Therefore, the epidermis was removed from carcasses when possible to aid in scar identification. Scar tissue, or the margins of larger scars, was highlighted on the epidermis with a livestock marker (AllWeather Twist-Stik livestock marker) (Fig. 2A) or on the dermis with a meat-marking crayon (Meatmark Crayons). A hand-drawn sketch was then made showing the positions of scars on paper manatee templates of dorsal, both lateral, and ventral views. Photographs were retaken of the carcass (showing marked scars) from the corresponding angles.

Scar pattern counts were obtained for the 2935 carcasses using the associated photographs, scar sketches, and necropsy reports. Scars were counted as a watercraft-related pattern if they (1) fit Text S1 wound types A-C $(2)$ consisted of a single large triangular or crescent-shaped scar; (3) consisted of evenly spaced mutilations of the fluke margin; (4) consisted of a large missing portion of the fluke that had a straight margin; or (5) were healing watercraft wounds that were not related to the cause of death.
Carcasses with 5 or fewer patterns were generally easy to count without additional steps. If a carcass appeared to have more than 5 patterns or if patterns overlapped and were difficult to discern, individual patterns on the scar sketch were highlighted in different colors to aid in separating and counting them (Fig. 2B). Scars were not counted as watercraftrelated if they were similar to healed scrapes or lesions not related to watercraft collisions (Text S3, Fig. S3). Healing wounds or well-healed scars associated with a chronic watercraft-related injury resulting in mortality were not included. Seventeen manatees that died from chronic watercraft-related injuries did not have a clearly identified scar or wound associated with the trauma. The models were also run by removing 1 scar pattern from each of these 17 carcasses and removing those carcasses completely from the study (those carcasses accounting for 159 scar patterns), which did not affect the results presented here.

To identify recording errors and evaluate consistency of scar pattern identification, 2 biologists (Biologist1, Biologist2) skilled in manatee necropsy independently examined carcass sketches and photographs as a check of the work of the third primary examiner. A random selection of carcasses was chosen for each biologist by utilizing a random number generator (Microsoft Excel, version 2013). Biologist1 and Biologist2 assessed 124 and 90 necropsy reports, respectively, for carcasses salvaged in $2007-$
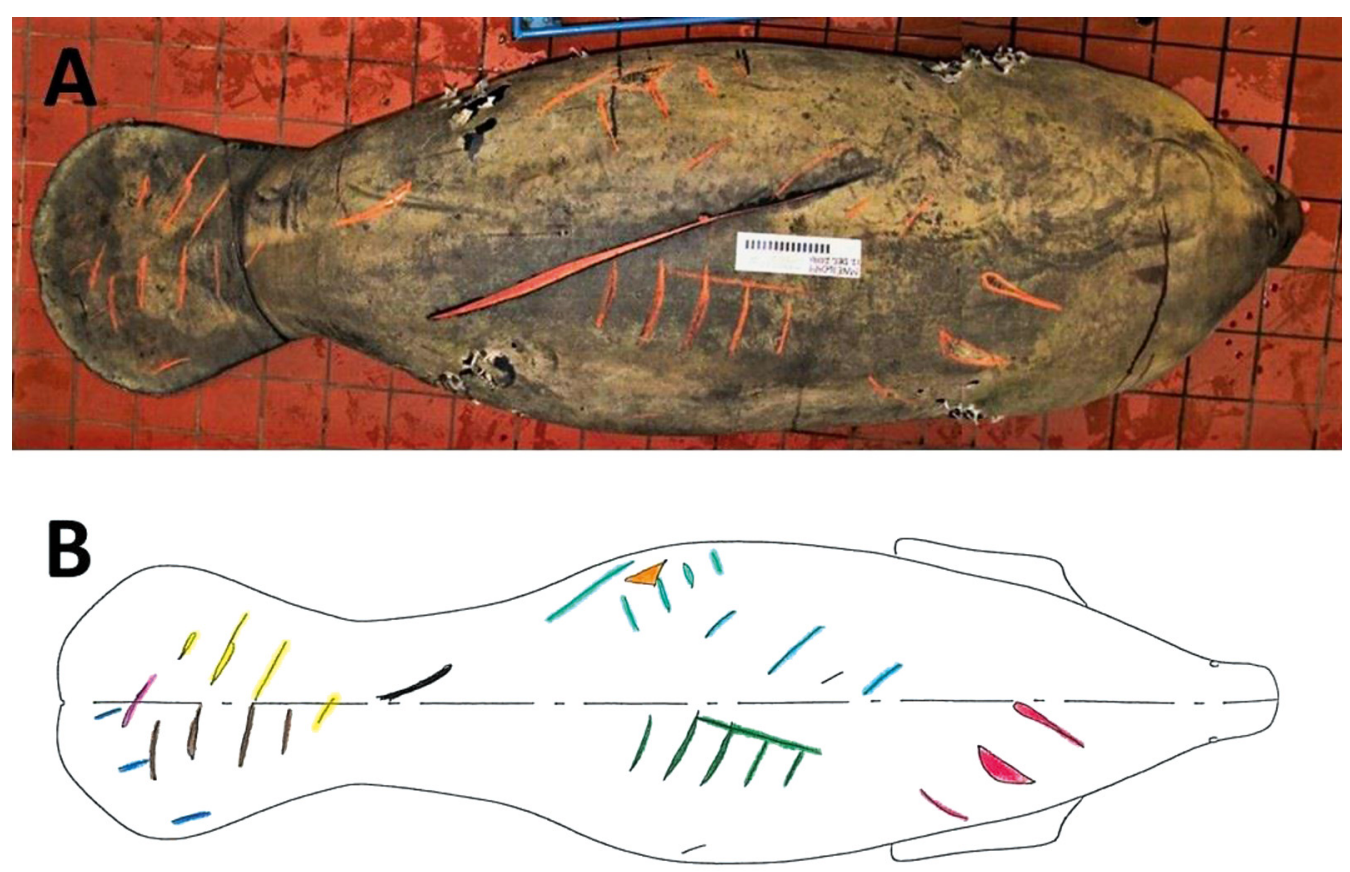

Fig. 2. (A) Manatee carcass with scars highlighted, awaiting necropsy and (B) color-coded sketch depicting separate scar patterns. The long fresh linear watercraft wound across the dorsum was not included in the scar sketch 
2009 that were also examined by the primary examiner. Twenty of these necropsy reports were assessed by all 3 examiners. Krippendorff's alpha-reliability coefficient (Hayes \& Krippendorff 2007) was used to assess the agreement of scar counts among examiners. Krippendorff's alpha ranges from 0 to 1 , where 0 corresponds with no agreement and 1 corresponds with perfect agreement. We used the 'irr' package (Gamer et al. 2019) in R (R Core Team 2019) to estimate Krippendorff's alpha for ratio values. The data were first analyzed before correcting for recording errors and resulted in an alpha $=0.849$. After correcting for recording errors, alpha $=0.871$. Anything greater than 0.75 is considered 'excellent' agreement (Cicchetti 1994). The average difference per carcass between the primary examiner and Biologist1 was 0.51 patterns with a maximum difference of 4 patterns on 1 carcass. The average difference per carcass between the primary examiner and Biologist2 was 0.46 patterns with a maximum difference of 3 patterns on 1 carcass. This demonstrated that our scar-counting technique was repeatable and reliable for use on a larger subset of manatee carcasses.

\subsection{Statistical analyses}

Individual scar patterns were analyzed regarding sex, life stage, population region, and year of death. We used generalized linear mixed models (Littell et al. 2006) to examine the effects of several factors on 2 response variables: (1) the presence or absence of scars on carcasses and (2) the number of scar patterns per carcass. All analyses were performed in SAS v.9.4, and significance was determined at the $\alpha=0.05$ level.

We first built a generalized linear mixed model (Model P) assuming a binary distribution to test for effects of life stage, generalized population region, sex, and all 2-way interactions on the probability of animals having scars. We included year of death as a random variable to account for year-to-year variability in the proportion of scarred animals. Nonsignificant interactions were removed from the final model.

We then built a generalized linear mixed model (Model N) assuming a negative binomial distribution to test for effects of region, sex, total length, and all 2way interactions with length on the number of scar patterns, again with year of death as a random effect. Nonsignificant interactions were removed from the final model.

Monroe County in southern Florida is split between the SW region (Florida Everglades) and the Atlantic (ATL) region (Florida Keys) (Fig. 1). Few manatee car- casses were reported from the SW portion of Monroe County, and recovered carcasses were often in a highly advanced stage of decomposition due to delays in discovery and long travel times to the site. Florida experienced an extensive cold event during winter 2010 (Barlas et al. 2011) that resulted in a relatively large number of reported carcasses in Monroe County ( $\mathrm{n}=47$ necropsied) and provided a unique opportunity to compare differences in the accumulation of scar patterns between animals collected in Monroe County and the remaining SW region. While analyzing the observed scar pattern counts, it was noted that Monroe County carcasses had fewer scar patterns than did the rest of the region. To analyze this difference, we built generalized linear models to test for differences between the portion of Monroe County within the SW region and the rest of the SW region and included length as a continuous covariate. We assumed a binary distribution for the presence or absence of scars (Model SW-P) and a negative binomial distribution for the number of scar patterns (Model SW-N).

We also tested whether scar pattern accumulation rates and the probability of scarring changed over time, but we limited our analyses to calves and subadults. Calves are generally less than 2 yr old, which limits to a relatively short time frame their exposure to watercraft. The subadult life stage generally includes animals 2-7 yr old, and this longer period increases their exposure to watercraft. We used a negative binomial regression model and a logistic regression model to test, respectively, for a linear effect of time on the number of scars on calves (Model C-N) and subadults (Model S-N) and the probability of scarring on calves (Model C-P) and subadults (Model S-P). In all 4 models, we included year of death and length as continuous fixed effects and region as a categorical fixed effect.

\section{RESULTS}

Across the 2935 carcasses included in the study, we documented 12358 watercraft-related scar patterns. We documented 10686 watercraft-related scar patterns on the 1385 adult-size carcasses in this study, or an average of 7.7 scar patterns. The 553 subadult carcasses had an average of 2 scar patterns, and the 997 calves had an average of 0.6 scar patterns. Of the 1385 adult-size carcasses, $25 \%$ had 10 or more scar patterns, and $7 \%$ had 20 or more patterns. The greatest number of watercraft-related scar patterns on 1 animal was 47 , on the carcass of an adult female recovered in the SW region. 
Table 2. Model P - estimated average $( \pm \mathrm{SE})$ percentage of Florida manatees with scarring, by life stage and sex. Calves: $>150$ and $<236 \mathrm{~cm}$ total straight length; subadults: $236-265 \mathrm{~cm}$; adults: $>265 \mathrm{~cm}$. Manatee carcasses were collected statewide during 2007-2016. Means sharing common letters were not significantly different $(p>0.05)$

\begin{tabular}{|lcc|}
\hline & Female (\%) & Male (\%) \\
\hline Adult & $96.6^{\mathrm{a}}( \pm 0.7)$ & $94.3^{\mathrm{b}}( \pm 1.0)$ \\
Subadult & $68.6^{\mathrm{c}}( \pm 3.7)$ & $71.5^{\mathrm{c}}( \pm 3.3)$ \\
Calf & $33.1^{\mathrm{d}}( \pm 3.7)$ & $34.2^{\mathrm{d}}( \pm 3.1)$ \\
\hline
\end{tabular}

\subsection{Proportion of scarred manatees}

Across all management regions, Model $\mathrm{P}$ indicated that $96 \%$ of adult-size carcasses had at least 1 watercraft-related scar pattern. There were no significant interactions between life stage and population region $\left(F_{6,2903}=\right.$ $0.79, \mathrm{p}=0.5768$ ) or between sex and population region $\left(F_{3,2903}=1.61, \mathrm{p}=\right.$ $0.1855)$ in the model-estimated proportion of animals with watercraftrelated scar patterns. There was a significant interaction between the adult life stage and sex $\left(F_{2,2903}=3.97\right.$, $\mathrm{p}=0.0190$; Table 2), suggesting that a slightly higher proportion of adult females had scars than adult males. A higher proportion of adults had scars than subadults, and a higher proportion of subadults had scars than calves (Table 2). The model-estimated proportion of animals with scars also varied significantly among regions $\left(F_{3,2903}=11.37, \mathrm{p}<0.001\right.$; Tables $3 \&$ A1 in the Appendix). The SW and NW regions had a higher proportion of scarred animals than did the ATL and Upper St. Johns (USJ) regions (Table 3). This was consistent across all life stages and sexes (Table A1).

\subsection{Number of scar patterns}

Within each region, more scar patterns were counted on adult females on average than on adult males (Fig. 3). When accounting for total body length, Model $\mathrm{N}$ showed that the number of scar patterns on males and females of the same length were not significantly different $\left(F_{1,2911}=2.61, \mathrm{p}=0.1062\right)$, nor was there a significant interaction between length and sex for the number of scar patterns $\left(F_{1,2911}=3.00, \mathrm{p}=0.0831\right)$. On average, adult females from this study were longer than adult males (Figs. S4 \& S5).

The number of scar patterns increased with total length (Figs. 4 \& A1), but the slope of this increase differed by region, as indicated by a significant interaction between management region and length $\left(F_{3,2911}=3.58, \mathrm{p}=0.0133\right)$. The slope was relatively shallow through the calf and subadult life stages but began to increase sharply with increasing length after the animals transitioned into the adult life stage, especially among large adults. The slope was sharpest in the NW and SW regions. The ATL had the next sharpest slope, and the USJ region had the shallowest slope.

Table 3. Model P-estimated average $( \pm \mathrm{SE})$ percentage of adult, subadult, and calf Florida manatee carcasses with scarring by management region. Percentages are averaged across males and females. Manatee carcasses were collected statewide during 2007-2016. Overall means sharing common letters are not significantly different $(\mathrm{p}>0.05)$

\begin{tabular}{|lcccc|}
\hline Management region & Adult (\%) & Subadult (\%) & Calf $(\%)$ & Overall (\%) \\
\hline Northwest & $97.6( \pm 0.7)$ & $81.5( \pm 4.0)$ & $48.8( \pm 6.3)$ & $84.7^{\mathrm{a}}( \pm 3.3)$ \\
Southwest & $96.7( \pm 0.5)$ & $75.8( \pm 2.2)$ & $40.5( \pm 2.2)$ & $79.8^{\mathrm{a}}( \pm 1.5)$ \\
Atlantic & $94.6( \pm 0.7)$ & $65.2( \pm 2.7)$ & $28.9( \pm 2.0)$ & $70.3^{\mathrm{b}}( \pm 1.8)$ \\
Upper St. Johns & $91.5( \pm 2.5)$ & $53.7( \pm 8.0)$ & $20.1( \pm 5.1)$ & $59.5^{\mathrm{b}}( \pm 7.5)$ \\
All regions & $95.6( \pm 0.7)$ & $70.1( \pm 2.9)$ & $33.7( \pm 2.7)$ & $74.7( \pm 2.1)$ \\
\hline
\end{tabular}

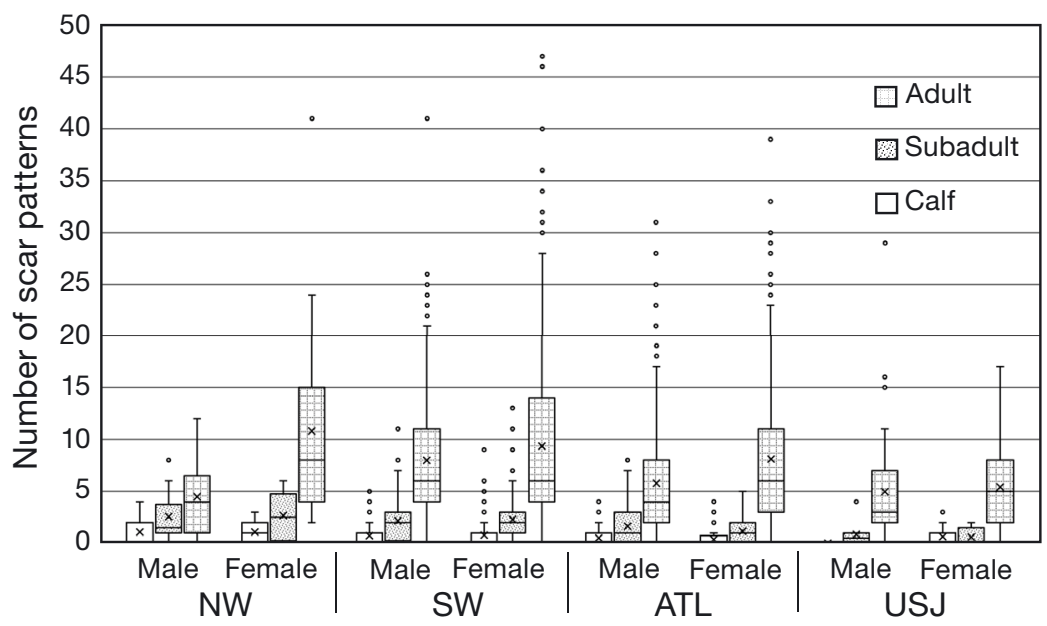

Fig. 3. Watercraft-related scar patterns by sex, life stage, and population region (see Fig. 1) for Florida manatees from 2007-2016. In each column, x: mean; middle horizontal line: median; bottom horizontal line: $1^{\text {st }}$ quartile; top horizontal line: $3^{\text {rd }}$ quartile; whiskers (vertical lines): minimum and maximum values, excluding outliers; points above the whiskers: outliers, defined as $>1.5 \times$ the interquartile range 


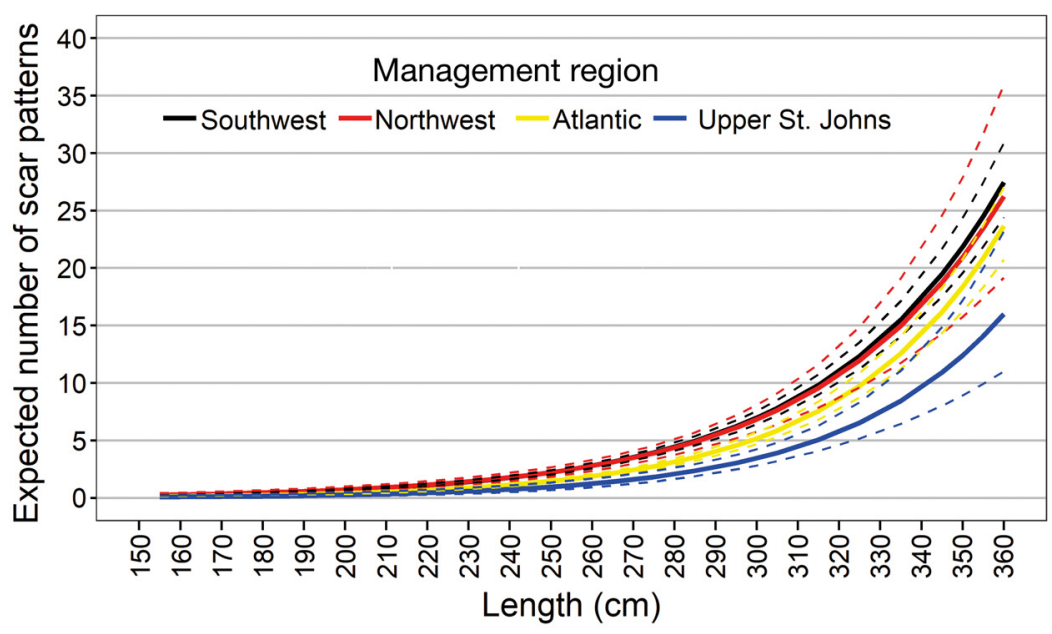

Fig. 4. Expected number of scar patterns by total straight length $(\mathrm{cm})$ of Florida manatees collected during 2007-2016 in the 4 management regions. Solid line: mean prediction; dashed lines: $95 \%$ CI

Table 4. Model SW-P - estimated percentage of Florida manatees with scars, and Model SW-N - estimated average $( \pm$ SE) number of scars, winter 2010 2011. We used the following average lengths for each life stage for model predictions: calves: $200 \mathrm{~cm}$; subadults: $251 \mathrm{~cm}$; adults: $304 \mathrm{~cm}$

\begin{tabular}{|lcccc|}
\hline & $\begin{array}{c}\text { Percentage of animals with scars } \\
\text { Southwest } \\
(\%)\end{array}$ & $\begin{array}{c}\text { Monroe County } \\
(\%)\end{array}$ & $\begin{array}{c}\text { Total number of scars } \\
\text { Southwest }\end{array}$ & Monroe County \\
\hline Adult & $91.2( \pm 5.7)$ & $59.7( \pm 16.1)$ & $7.9( \pm 2.7)$ & $1.5( \pm 0.5)$ \\
Subadult & $67.1( \pm 7.3)$ & $22.6( \pm 8.0)$ & $2.1( \pm 0.3)$ & $0.4( \pm 0.1)$ \\
Calves & $30.0( \pm 12.9)$ & $5.8( \pm 4.3)$ & $0.6( \pm 0.2)$ & $0.1( \pm 0.1)$ \\
\hline
\end{tabular}

\subsection{Monroe County versus the remaining SW region}

Carcasses of all life stages collected during the abnormally cold winter of 2010 in the portion of Monroe County within the SW region had significantly fewer scar patterns than those collected in the rest of the SW region during that period (Table 4). The proportion of manatees with scars $\left(F_{1,103}=10.43, \mathrm{p}=\right.$ $0.0017)$ and the number of scar patterns $\left(F_{1,103}=\right.$ 28.69, $\mathrm{p}<0.001$ ) were far greater in the northern SW region than in Monroe County.

\subsection{Changes in scar accumulation over time}

When we controlled for the effects of region and length, there was no increase in the number of scar patterns on subadults across the $10 \mathrm{yr}$ study period (Model S-N: $\left.F_{1,547}=0.02, \mathrm{p}=0.8965\right)$, nor was there a change in the probability of scarring among years
(Model S-P: $\left.F_{1,547}=1.98, \mathrm{p}=0.1604\right)$. But the number of scar patterns on subadults did increase with length (Model S-N: $F_{1,547}=19.30, \mathrm{p}<0.001$ ), as did the probability of scarring (Model S-P: $\left.F_{1,547}=10.85, \mathrm{p}=0.001\right)$. There was also a significant effect of region on both the number of scars $\left(\right.$ Model S-N: $\left.F_{1,547}=10.52, \mathrm{p}<0.001\right)$ and the probability of scarring (Model S-P: $\left.F_{3,547}=5.19, \mathrm{p}<0.001\right)$. When we controlled for the effects of region and length for calves over the same period, the number of scar patterns (Model C-N) and the probability of scarring (Model C-P) increased over time, though neither effect was significant $\left(F_{1,991}=3.49, \mathrm{p}=0.0622\right.$ and $F_{1,991}=3.62, \mathrm{p}=0.0572$, respectively; Fig. 5). Similar to that in subadults, the number of scar patterns on calves increased with length (Model C-N: $\left.F_{1,991}=95.58, \mathrm{p}<0.001\right)$, as did the probability of scarring (Model C-P: $\left.F_{1,991}=102.82, \mathrm{p}=0.001\right)$, and there was also a significant effect of region on both the number of scars $\left(\right.$ Model C-N: $\left.F_{1,991}=9.14, \mathrm{p}<0.001\right)$ and the probability of scarring (Model C-P: $\left.F_{3,991}=6.01, \mathrm{p}=0.001\right)$.

\section{DISCUSSION}

Our understanding of the frequency of collisions between manatees and watercraft is broadened by using well-healed scar patterns found on carcasses. This study provides wildlife managers with additional information on the ever-present threats manatees face from watercraft and will help quantify the sublethal effects of boat strikes. We demonstrated that sublethal injuries from watercraft collisions varied with sex, life stage, and region across a 10 yr time frame. It was expected that the number of scar patterns would be greatest in adults, followed by subadults and then calves, which have had the least time to accumulate scars. One in 4 manatees that reach adulthood is hit by watercraft at least 10 times. The long-term consequences of sublethal injury resulting in scarring are not fully understood, but short-term consequences include pain, elevated stress responses, and behavioral changes, as well as increased energy expenditure (Felleiter et al. 2017, 


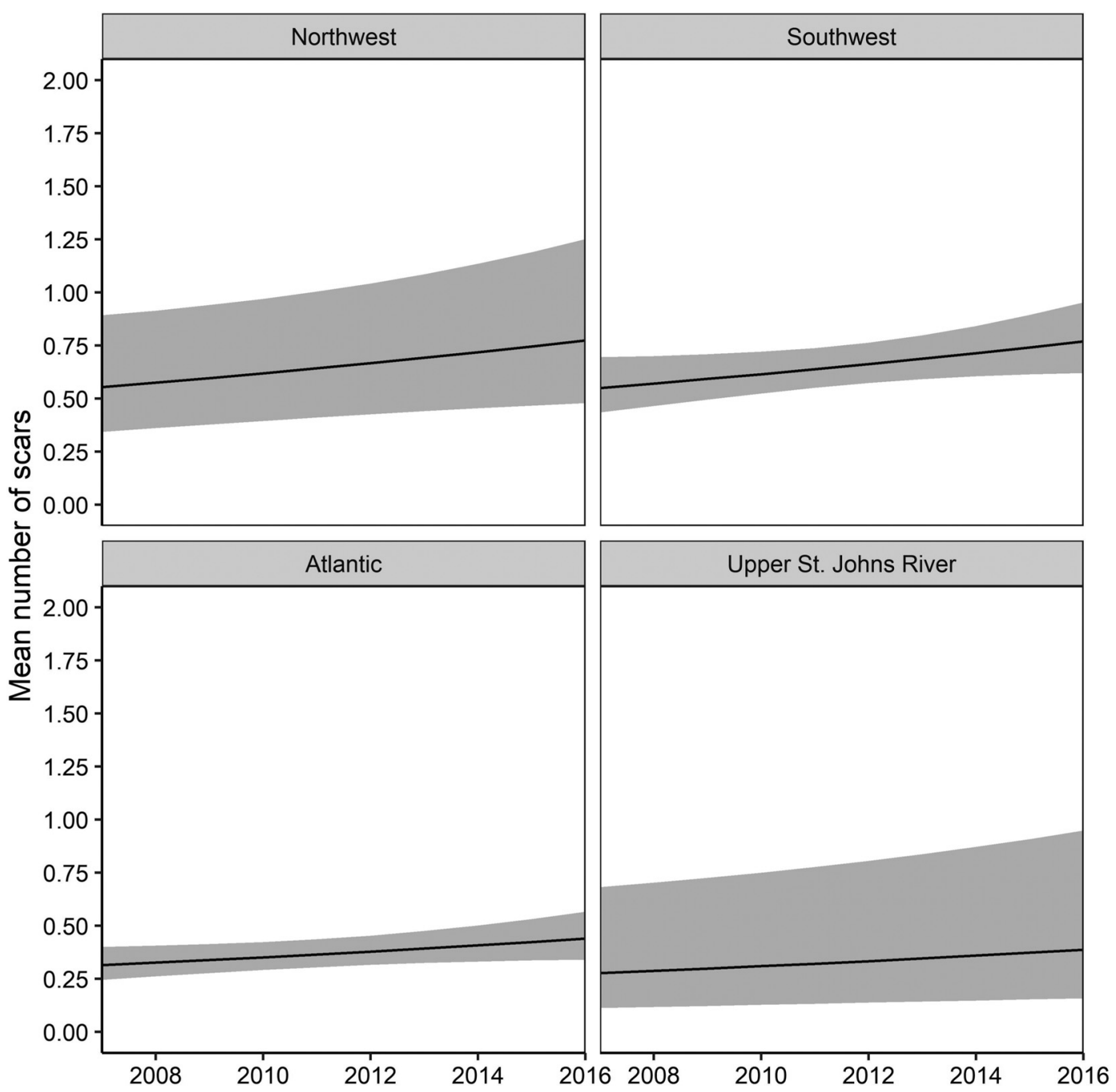

Fig. 5. Model C-N - estimated mean number of scar patterns on Florida manatee calves of average length (200 cm), $2007-2016$ $\left(F_{1,991}=3.49, \mathrm{p}=0.0622\right)$. Shaded regions: upper and lower $95 \%$ confidence limits

Lysiak et al. 2018). Longer-term impacts include decreased mobility due to skeletal remodeling of fractured bone (Wright et al. 1995), decreased swimming efficiency if large portions of the fluke are lost (Kojeszewski \& Fish 2007), compromised immune function (Valvis et al. 2015), and, if reproductive systems are damaged, decreased reproductive output.

\subsection{Proportion of scarred animals}

Model $\mathrm{P}$ indicated that approximately $96 \%$ of all adult manatees whose carcasses were examined in this study had been hit by a watercraft (Table 2). Because not all watercraft strikes leave permanent scars (FWC unpubl. data), this percentage could be even higher. This is in stark contrast to figures for other marine mammal species. Within a large resident population of common bottlenose dolphins Tursiops truncatus near Sarasota, FL, a region of high watercraft density shared with manatees, only 17 dolphins were reported with watercraft wounds or scars from 1993 through 2014 (Wells et al. 2008, Christiansen et al. 2016). Although California pinnipeds lead lives very different from those of the manatee (pinnipeds spend extensive periods on land), only $0.1 \%$ of more than 6000 live stranded animals across 6 species showed signs of watercraftrelated trauma in 1 study (Goldstein et al. 1999). One dugong photo-identification study found no scars on live animals attributable to boat propellers (Anderson 1995), although boat density was relatively low in the region. Among humpback whales in the Gulf of Maine, $14.7 \%$ of live individuals had at least 1 
watercraft-related scar pattern, with a maximum of 4 scar patterns seen on 2 individuals (Hill et al. 2017). It appears that manatees are the only marine mammal species struck to such a high level by watercraft. Some manatees outside of the USA, while possibly not struck to the same degree as Florida manatees, may be struck at higher proportions than other marine mammal species. Antillean manatees Trichechus manatus manatus of all life stages were captured in Belize from 1997 through 2019 ( $\mathrm{n}=163$ ) during research. Across all life stages, $33 \%(n=54)$ of those manatees had at least 1 watercraft-related scar (J. Galves pers. comm.). Self-Sullivan (2007) found that $44 \%$ of free-swimming Antillean manatees in Belize that were video-captured from 1999-2005 had watercraft-related scars. A variety of factors might contribute to nearly every adult Florida manatee's being struck by a watercraft at least once in its life. Manatees inhabit shallow coastal and river systems, which also have high volumes of watercraft traffic. Because manatees spend most of their time at shallow depths (Ross 2007), mostly within $1.25 \mathrm{~m}$ of the surface (Edwards et al. 2016), their chance of encounters with watercraft is greatly increased. Manatees are also slow moving compared with dolphins and pinnipeds.

\subsection{Regional variation in scarring}

Patterns of watercraft-related scar accumulation as a function of sex and life stage were generally comparable at the regional scale (Fig. 3), but Model P showed that the proportion of carcasses with at least 1 scar pattern was significantly higher for carcasses collected on the west coast of Florida than for those collected on the east coast (Table 3 ). The similarity in scarring within each coast may partly reflect individual movement between intracoastal regions (NW and SW, ATL and USJ); consequently, the region in which a manatee carcass is recovered does not necessarily reflect where that animal received all of its scars over its lifetime. But because most manatees appear to remain within 1 population region over the course of a year, we think that these results should be fairly representative of regional scarring rates. Although there was not a significant difference between the USJ and ATL regions regarding the overall proportion of carcasses with at least 1 scar pattern, USJ region adult carcasses had fewer scar patterns than did those from any of the other regions (Fig. 4). The similarities between the NW and SW regions, and differences between the ATL and USJ regions and between coasts may also be influenced by factors like topography, vessel types, or manatee and human behavior.

In comparison, Runge et al. (2017) used carcass data from 1995-2013 to estimate, for each management region, the fraction of mortality resulting from 6 key causes of manatee deaths. They found that watercraft collisions were the leading cause of mortality across life stages and regions, which, together with our Model P findings showing that the majority of manatees are scarred in all regions, indicates that manatee-watercraft collisions have broad impacts across Florida. But watercraft mortality probability estimates (watercraft fraction of mortality times total mortality) for subadults/adults were highest for ATL and lowest for NW (Runge et al. 2017). Our study found both fewer scar patterns and fewer scarred animals in the ATL and USJ regions. Many factors can influence the risk of both lethal and sublethal collisions between boats and manatees (e.g. boat characteristics, manatee characteristics, habitat; Martin et al. 2016, Rycyk et al. 2018, Udell et al. 2019), which vary at spatiotemporal scales smaller than those considered here. At the regional level, registered vessels in Florida are split relatively evenly between the coasts, so broadly characterized vessel concentrations are not sufficient to explain the differences in manatee scarring between management regions (https:// www.flhsmv.gov/pdf/vessels/vesselstats2016.pdf).

A closer examination was performed comparing carcasses necropsied from the Everglades portion of Monroe County (portion in the SW region) and the rest of the SW region. Model SW-N showed that Monroe County manatees at all life stages had significantly fewer watercraft-related scar patterns than did manatees in the rest of the SW region, and Model SW-P showed similar findings for the proportion of scarred animals (Table 4). The Everglades encompasses some of the most remote habitats in the state, often accessible only by boat. When compared with some of the highly populated regions of the state, the Monroe County subregion had a relatively low concentration of watercraft traffic, and recorded watercraft-related manatee mortality is low, but watercraft concentrations and watercraft-related deaths were notably higher just north of the Monroe County line (Stith et al. 2006). Satellite tracking data suggest that a population of manatees exists that has high site fidelity to the remote Everglades region within Monroe County, while manatees north of this region do not frequent that portion of the Everglades (Weigle et al. 2001, Stith et al. 2006). This remote subregion appears to have a lower risk of watercraft collisions 
with manatees. Recent genetic research on manatees from this region could shed more light on these findings, and future tagging work might concentrate on that subpopulation.

It is also interesting to note that even though scar pattern totals differed by region, each region had a relatively small number of outliers with very high scar counts (Fig. 3). These outliers may be the result of long-lived individuals that accumulated scars over decades, or perhaps individuals with fidelity to sites with conditions (watercraft density, topography, etc.) that may contribute to risk of watercraft encounters.

\subsection{Sex differences in scarring}

Model P showed that a slightly higher proportion of adult females had scars than did adult males (Table 2), and female carcasses collected during the study period had more scar patterns on average than did adult males. Females might live longer than males, giving females more time to accumulate scars, but research has shown little evidence of sex-related differences in adult survival (Langtimm et al. 2004). Sex-specific behavioral and life history differences may better explain the different rates of scar pattern accumulation. For instance, pregnant females have higher energy needs and spend increased time foraging in shallow seagrass beds (Ross 2007), and adult females invest in long periods of calf-rearing. Female life history characteristics and habitat use could result in increased exposure to watercraft (Ross 2007, Edwards et al. 2016). Females with young calves may spend more time in shallow or surface waters or moving more slowly for the calf's benefit during its first months of life (M. Ross pers. comm.). More research would be needed to investigate this sexual difference in accumulated scar patterns.

The number of scar patterns did not differ significantly between sexes, however, when accounting for the effect of length. Adult females were consistently longer than males in the present study (Figs. S4 \& S5), and there is evidence that males' growth rate slows relative to females' after animals reach approximately $300 \mathrm{~cm}$ in total length (Schwarz \& Runge 2009, Lonati et al. 2019: particularly their Fig. 7). Thus, adult female manatees longer than $300 \mathrm{~cm}$ may be younger than males of the same length. If younger adult females and older adult males of the same total length have the same number of scar patterns, then that implies that adult females accumulate scar patterns at a faster rate than adult males. Assuming similar lifespans for male and female manatees, this could also explain why adult females had more observed scar patterns overall (results of Model N).

\subsection{Scar accumulation over time}

The goal of this work was to advance our understanding of the occurrence of sublethal watercraftrelated impacts on the Florida manatee. One aspect of addressing this goal included describing measurable changes in scar accumulation over time. Wright et al. (1995) determined that 628 manatee carcasses from 1979 through 1991 had a total of 1376 wound and scar patterns. But comparing current work to previous research is problematic because of differences in counting methods (Wright et al. 1995 did not include unscarred carcasses and combined scar and wound pattern counts). Also, carcass detection and reporting rates may have been lower during the initial years of the carcass salvage program (Runge 2003, Calleson 2014). We defined life stages based on length rather than age estimates in 4 models (C$\mathrm{P}, \mathrm{C}-\mathrm{N}, \mathrm{S}-\mathrm{P}, \mathrm{S}-\mathrm{N})$ to test for changes over time. Because the adult life stage can include an age range of 50 yr or more and scars counted at the time of death are a cumulative indicator, it is not possible to determine changes in scar accumulation over time based solely on adult carcass length. Manatees of the calf and subadult life stages, however, could be useful to this end, as these stages include a smaller age range than adults. When examining subadults for trends across the $10 \mathrm{yr}$ period of this study (Models S-P and S-N), a general increase was observed. Lonati et al. (2019) found that animals in the subadult size category had an approximate age range of 2-10 yr based on counts of growth layers in earbones, although most were 2-6 yr old. There may be too much age variation to rely on subadult lengths for this analysis. Calf ages in the Lonati et al. (2019) study ranged from 0-2 yr, so scar pattern analysis on calves could suggest short-term changes in manatee-watercraft collisions. Model C-N indicated a slight increase in the number of scar patterns in the calf group over time in each region (Fig. 5), but the differences were not significant. Model C-P also did not show a significant difference in the proportion of scarred calves. Using estimated ages from earbone readings instead of life stages could provide a more reliable estimate of this increase as well as estimates of nonlethal watercraft strike rates. This information could be useful as a metric in decision analyses when evaluating and tracking changes in watercraft impacts. 


\section{CONCLUSIONS}

One-quarter of adult carcasses analyzed in the present study bore evidence of 10 or more watercraft strikes. With only $4 \%$ of adults devoid of watercraftrelated scars, it appears exceedingly rare that individuals reach late adulthood without having been struck multiple times. This study shows that manatees are subjected to more sublethal watercraft strikes than any other studied marine mammal. Analysis of temporal changes in scarring rates (Models C-N and S-N) did not indicate significant changes over the 2007-2016 time span, which is encouraging, especially in light of high estimated adult survival rates and improved abundance estimates (Runge et al. 2017, Hostetler et al. 2018). Even though the significant portion of watercraft-related mortality and morbidity often garners the most attention, here we provide new insights into the number of sublethal injuries inflicted by watercraft, which could have implications for health, behavior, and reproductive success in the Florida manatee.

Acknowledgements. We thank Andrew Garrett, Kari Rood, and Charles J. Deutsch for their technical support and guidance and Andrea Krzystan and Max Nausbaum for their GIS and mapping assistance. We also thank all of the FWC staff and volunteers and partners who have collected and necropsied the thousands of manatee carcasses used in this study. The corresponding author would also like to thank Kim Bassett for her help with organizing a portion of the SW-region data. Thanks to Scott Calleson, Robert Muller, Martine de Wit, and Tom Pitchford for review of the manuscript. Thanks to the FWRI PPO copy-editor, journal editor, and anonymous peer-reviewers for their constructive input and assistance.

\section{LITERATURE CITED}

Anderson PK (1995) Scarring and photoidentification of dugongs (Dugong dugon) in Shark Bay, Western Australia. Aquat Mamm 21:205-211

Barlas ME, Deutsch CJ, de Wit M, Ward-Geiger LI (eds) (2011) Florida manatee cold-related unusual mortality event, January-April 2010. Final report to USFWS (grant 40181AG037). Florida Fish and Wildlife Conservation Commission, St. Petersburg, FL

Beck CA, Reid JP (1995) An automated photo-identification catalog for studies of the life history of the Florida manatee. In: O'Shea TJ, Ackerman BB, Percival HF (eds) Population biology of the Florida manatee. Information and Technology Report 1. National Biological Service, US Department of the Interior, Washington, DC, p 120-134

Beck CA, Bonde RK, Rathbun GB (1982) Analyses of propeller wounds on manatees in Florida. J Wildl Manag 46: 531-535

Bengtson JL (1981) Ecology of manatees (Trichechus manatus) in the St. Johns River, Florida. PhD thesis, University of Minnesota, Minneapolis, MN
Bonde RK, O'Shea TJ, Beck CA (1983) Manual of procedures for the salvage and necropsy of carcasses of the West Indian manatee (Trichechus manatus). Report No. PB83-255273, National Technical Information Service, US Department of Commerce, Alexandria, VA

Calleson SC (2014) Issues and opportunities associated with using manatee mortality data to evaluate the effectiveness of manatee protection efforts in Florida. Endang Species Res 26:127-136

Calleson CS, Frohlich KR (2007) Slower boat speeds reduce risks to manatees. Endang Species Res 3:295-304

* Christiansen F, McHugh KA, Bejder L, Siegal EM and others (2016) Food provisioning increases the risk of injury in a long-lived marine top predator. R Soc Open Sci 3:160560

Cicchetti DV (1994) Guidelines, criteria, and rules of thumb for evaluating normed and standardized assessment instruments in psychology. Psychol Assess 6:284-290

Conn PB, Silber GK (2013) Vessel speed restrictions reduce risk of collision-related mortality for North Atlantic right whales. Ecosphere 4:43

Deutsch CJ, Reid JP, Bonde RK, Easton DE, Kochman HI, O'Shea TJ (2003) Seasonal movements, migratory behavior, and site fidelity of West Indian manatees along the Atlantic coast of the United States. Wildl Monogr 151:1-77

Edwards HH, Martin J, Deutsch CJ, Muller RG, Koslovsky SM, Smith AJ, Barlas ME (2016) Influence of manatees' diving on their risk of collision with watercraft. PLOS ONE 11: e0151450

Felleiter P, Krebs J, Haeberli Y, Schmid W, Tesini S, Perret C (2017) Post-traumatic changes in energy expenditure and body composition in patients with acute spinal cord injury. J Rehabil Med 49:579-584

*Fonnesbeck CJ, Garrison LP, Ward-Geiger LI, Baumstark RD (2008) Bayesian hierarchical model for evaluating the risk of vessel strikes on North Atlantic right whales in the SE United States. Endang Species Res 6:87-94

FWC (Florida Fish and Wildlife Conservation Commission) (2007) Florida manatee management plan. FWC, Tallahassee, FL

Gamer M, Lemon J, Fellows I, Singh P (2019) Package irr: coefficients of interrater reliability and agreement for quantitative, ordinal and nominal data. https://cran. r-project.org/web/packages/irr/index.html

Goldstein T, Johnson SP, Phillips AV, Hanni KD, Fauquier DA, Gulland FMD (1999) Human-related injuries observed in live-stranded pinnipeds along the central California coast 1986-1998. Aquat Mamm 25:43-51

Hayes A, Krippendorff K (2007) Answering the call for a standard reliability measure for coding data. Commun Methods Meas 1:77-89

Hazel J, Gyuris E (2006) Vessel-related mortality of sea turtles in Queensland, Australia. Wildl Res 33:149-154

Hazel J, Lawler IR, Marsh H, Robison S (2007) Vessel speed increases collision risk for the green turtle Chelodina mydas. Endang Species Res 3:105-113

Hill AN, Karniski C, Robbins J, Pitchford T, Todd S, Asmutis-Silvia R (2017) Vessel collision injuries on live humpback whales, Megaptera novaeangliae, in the southern Gulf of Maine. Mar Mamm Sci 33:558-573

Hostetler JA, Edwards HH, Martin J, Schueller P (2018) Updated statewide abundance estimates for the Florida manatee. Technical Report TR-23. Fish and Wildlife Research Institute, Florida Fish and Wildlife Conservation Commission, St. Petersburg, FL 
Kendall WL, White GC, Hines JE, Langtimm CA, Yoshizaki J (2012) Estimating parameters of hidden Markov models based on marked individuals: use of robust design data. Ecology 93:913-920

Kipps EK (2000) Structure and function of the skin of the Florida manatee (Trichechus manatus latirostris). MS thesis, University of North Carolina at Wilmington, Wilmington, NC

Kipps EK, McLellan WA, Rommel SA, Pabst DA (2002) Skin density and its influence on buoyancy in the manatee (Trichechus manatus latirostris), harbor porpoise (Phoca phocoena), and bottlenose dolphin (Tursiops truncates). Mar Mamm Sci 18:765-778

Kojeszewski T, Fish FE (2007) Swimming kinematics of the Florida manatee (Trichechus manatus latirostris): hydrodynamic analysis of an undulatory mammalian swimmer. J Exp Biol 210:2411-2418

Langtimm CA, Beck CA, Edwards HH, Fick-Child KJ, Ackerman BB, Barton SL, Hartley WC (2004) Survival estimates for Florida manatees from the photo-identification of individuals. Mar Mamm Sci 20:438-463

Langtimm CA, Kendall WL, Beck CA, Kochman HI, Teague AL, Meigs-Friend G, Peñaloza CL (2016) Model description and evaluation of the mark-recapture survival model used to parameterize the 2012 status and threats analysis for the Florida manatee (Trichechus manatus latirostris). Open-File Report 2016-1163, US Geological Survey, Reston, VA

Lightsey JD, Rommel SA, Costidis AM, Pitchford TD (2006) Methods used during gross necropsy to determine watercraft-related mortality in the Florida manatee (Trichechus manatus latirostris). J Zoo Wildl Med 37:262-275

Littell C, Milliken GA, Stroup WW, Wolfinger RD, Schabenberger O (2006) SAS ${ }^{\circledR}$ for mixed models, $2^{\text {nd }}$ edn. SAS Institute, Cary, NC

Lonati GL, Howell AR, Hostetler JA, Schueller P and others (2019) Accuracy, precision, and error in age estimation of Florida manatees using growth layer groups in earbones. J Mammal 100:1350-1363

Lysiak NSJ, Trumble SJ, Knowlton AR, Moore MJ (2018) Characterizing the duration and severity of fishing gear entanglement on a North Atlantic right whale (Eubalaena glacialis) using stable isotopes, steroid and thyroid hormones in baleen. Front Mar Sci 5:168

Martin J, Sabatier Q, Gowan TA, Giraud C and others (2016) A quantitative framework for investigating risk of deadly collisions between marine wildlife and boats. Methods Ecol Evol 7:42-50

O'Shea TJ, Lefebvre LW, Beck CA (2001) Florida manatees: perspectives on populations, pain, and protection. In: Dierauf LA, Gulland FMD (eds) CRC handbook of marine mammal medicine, $2^{\text {nd }}$ edn. CRC Press, Boca Raton, FL, p 31-43

R Core Team (2019) R: a language and environment for statistical computing. R Foundation for Statistical Computing, Vienna

Rathbun GB, Reid JP, Carowan G (1990) Distribution and movement patterns of manatees (Trichecus manatus) in northwestern peninsular Florida. Publication No 48. Florida Marine Research Institute, St. Petersburg, FL

Reid JP, Rathbun GB, Wilcox JR (1991) Distribution patterns of individually identifiable west Indian manatees (Trichechus manatus) in Florida. Mar Mamm Sci 7:180-190

Rommel SA, Costidis AM, Pitchford TD, Lightsey HD, Snyder RG, Haubold EM (2007) Forensic methods for characterizing watercraft from watercraft-induced wounds on the Florida manatee (Trichechus manatus latirostris). Mar Mamm Sci 23:110-132

Ross M (2007) Seasonal and diel patterns of manatee habitat use. MS thesis, Florida State University, Orlando, FL

Runge MC (2003) Appendix I: model for assessing incidental take of manatees due to watercraft-related activities. US Fish and Wildlife Service, Environmental impact statement: rulemaking for the incidental take of small numbers of Florida manatees (Trichechus manatus latirostris) resulting from government programs related to watercraft access and watercraft operation in the state of Florida. US Fish and Wildlife Service, Jacksonville, FL

Runge MC, Sanders-Reed CA, Langtimm CA, Hostetler JA and others (2017) Status and threats analysis for the Florida manatee (Trichechus manatus latirostris), 2016. Scientific Investigation Report 2017-5030. US Geological Survey, Reston, VA

Rycyk AM, Deutsch CJ, Barlas ME, Hardy SK, Frisch K, Leone EH, Nowacek DP (2018) Manatee behavioral response to boats. Mar Mamm Sci 34:924-962

* Schwarz LK, Runge MC (2009) Hierarchical Bayesian analysis to incorporate age uncertainty in growth curve analysis and estimates of age from length: Florida manatee (Trichechus manatus) carcasses. Can J Fish Aquat Sci 66: 1775-1789

Self-Sullivan C (2007) Non-lethal boat scars on manatees in Belize as a tool for evaluation of a Marine Protected Area - preliminary results. Proc Gulf Caribb Fish Inst 59: 535-540

Singel K, Foley A, Bailey R (2008) Navigating Florida's waterways: boat related strandings of marine turtles in Florida. In: Rees A, Frick M, Panagopoulou A, Williams K (eds) Proc $27^{\text {th }}$ Ann Symp Sea Turtle Biol Conserv. NOAA Tech Memo NMFS-SEFSC-569. National Marine Fisheries Service, Miami, FL, p 110

Sobin JM, Eckert S (2008) Diving behavior of female loggerhead turtles (Caretta caretta) during their internesting interval and an evaluation of the risk of boat strikes. MEM thesis, Duke University, Durham, NC

Stith BM, Slone DH, Reid JP (2006) Review and synthesis of manatee data in Everglades National Park. USGS Administrative Report. Florida Integrated Science Center, US Geological Survey, Gainesville, FL

* Stone GS, Yoshinaga A (2000) Hector's dolphin (Cephalorhynchus hectori) calf mortalities may indicate new risks from boat traffic and habituation. Pac Conserv Biol 6: $162-170$

Udell BJ, Martin J, Fletcher RJ Jr, Bonneau M and others (2019) Integrating encounter theory with decision analysis to evaluate collision risk and determine optimal protection zones for wildlife. J Appl Ecol 56:1050-1062

USFWS (US Fish and Wildlife Service) (2001) Florida manatee recovery plan, (Trichechus manatus latirostris), third revision. US Fish and Wildlife Service, Atlanta, GA

Valvis SM, Waithman J, Wood FM, Fear MW, Fear VS (2015) The immune response to skin trauma is dependent on the etiology of injury in a mouse model of burn and excision. J Invest Dermatol 135:2119-2128

Weigle BL, Wright IE, Ross M, Flamm RO (2001) Movements of radio-tagged manatees in Tampa Bay and along Florida's west coast 1991-1996. Tech Rep TR-7. Florida Marine Research Institute, Florida Fish and Wildlife Conservation Commission, St. Petersburg, FL

Wells RS, Scott MD (1997) Seasonal incidence of boat strikes 
on bottlenose dolphins near Sarasota, Florida. Mar Mamm Sci 13:475-480

Wells RS, Allen JB, Hofmann S, Bassos-Hull K and others (2008) Consequences of injuries on survival and reproductive of common bottlenose dolphins (Tursiops truncates) along the west coast of Florida. Mar Mamm Sci 24: 774-794
Wright SD, Ackerman BB, Bonde RK, Beck CA, Banowetz DJ (1995) Analysis of watercraft-related mortality of manatees in Florida 1979-1991. In: O'Shea TJ, Ackerman BB, Percival HF (eds) Population biology of the Florida manatee. Information and Technology Report No. 1. National Biological Service, Washington, DC, p 259-268

\section{Appendix.}

Table A1. The Model P-estimated proportion and standard error of mean $( \pm$ SEM) of Florida manatees with scarring by management region (see Fig. 1), sex, and age class. Calves: $>150$ and $<236 \mathrm{~cm}$ total straight length; subadults: 236-265 cm; adults: $>265 \mathrm{~cm}$. Manatee carcasses were collected statewide from 2007-2016

\begin{tabular}{|lcc|}
\hline & $\begin{array}{c}\text { Proportion of scarred } \\
\text { Florida manatees }\end{array}$ & \pm SEM \\
\hline NW female adult & 98.2 & 0.6 \\
NW male adult & 96.9 & 0.9 \\
NW female subadult & 80.4 & 4.4 \\
NW male subadult & 82.5 & 4.0 \\
NW female calf & 48.2 & 6.5 \\
NW male calf & 49.5 & 6.5 \\
SW female adult & 97.4 & 0.5 \\
SW male adult & 95.7 & 0.8 \\
SW female subadult & 74.5 & 3.0 \\
SW male subadult & 77.1 & 2.6 \\
SW female calf & 39.9 & 2.8 \\
SW male calf & 41.1 & 2.7 \\
ATL female adult & 95.8 & 0.8 \\
ATL male adult & 93.0 & 1.2 \\
ATL female subadult & 63.6 & 3.7 \\
ATL male subadult & 66.8 & 3.2 \\
ATL female calf & 28.4 & 2.6 \\
ATL male calf & 29.4 & 2.4 \\
USJ female adult & 93.3 & 2.3 \\
USJ male adult & 89.2 & 3.3 \\
USJ female subadult & 52.0 & 8.5 \\
USJ male subadult & 55.4 & 5.2 \\
USJ female calf & 19.7 & 5.3 \\
USJ male calf & 20.5 & \\
\hline
\end{tabular}




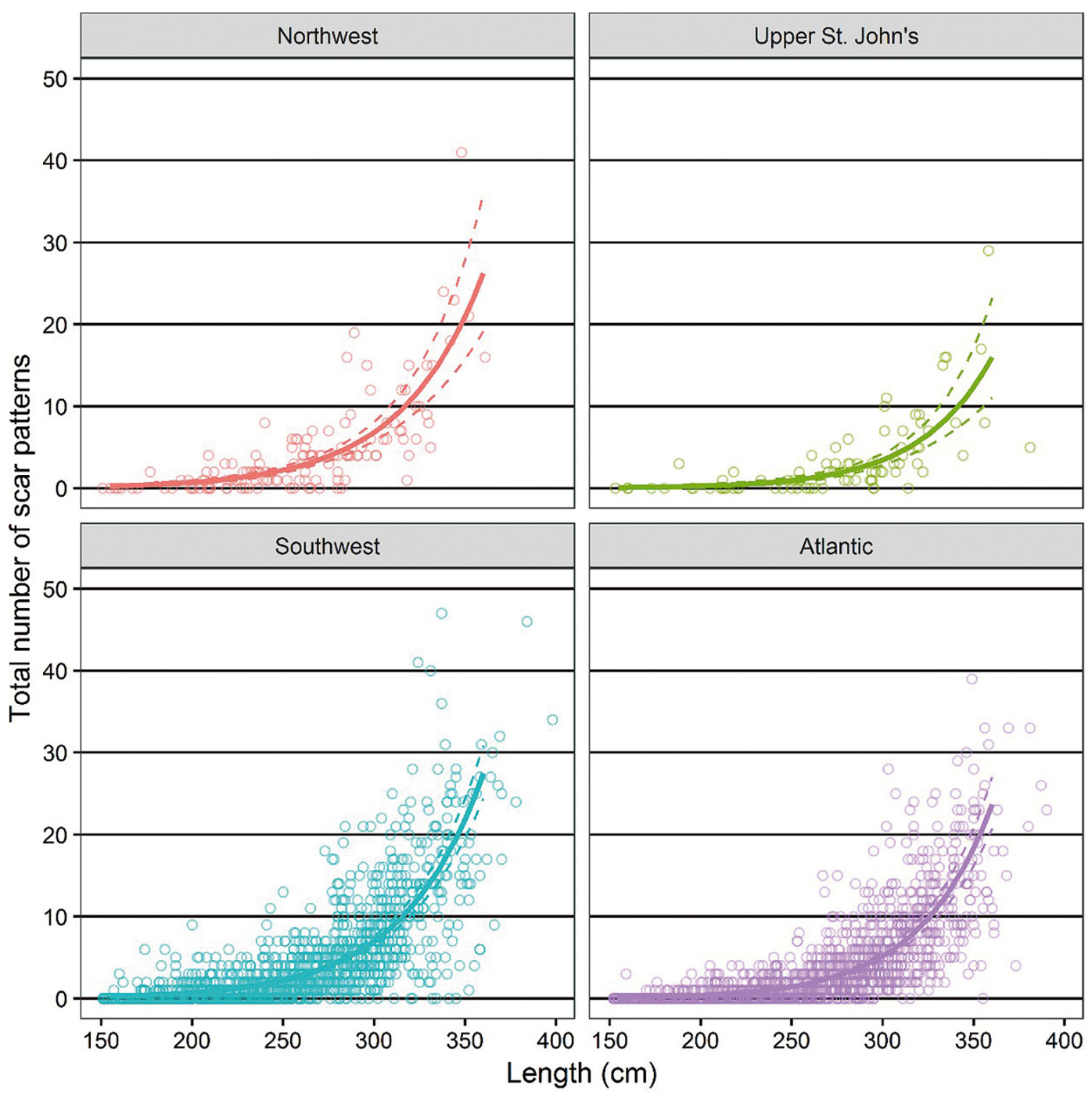

Fig. A1. Number of scar patterns versus total straight length $(\mathrm{cm})$ of Florida manatees collected during $2007-2016$ in the 4 management regions (see Fig. 1). Calves: $>150$ and $<236 \mathrm{~cm}$ total straight length; subadults: $236-265 \mathrm{~cm}$; adults: $>265 \mathrm{~cm}$. Solid line: mean prediction; dashed lines: $95 \%$ CI

Editorial responsibility: Helene Marsh, Townsville, Queensland, Australia
Submitted: April 22, 2020; Accepted: September 7, 2020 Proofs received from author(s): November 24, 2020 